\title{
Prediction of Distress and Identification of Potential M\&As Targets in UK
}

\author{
Dimitrios Gounopoulos \\ Surrey Business School, University of Surrey \\ Guildford, UK \\ Dionysis Polemis \\ School of Management, University of Liverpool \\ Liverpool, UK \& \\ Business College of Greece, Athens
}

\begin{abstract}
Purpose - This study seeks to identify financial characteristics that can be employed to assess and predict corporate financial distress in publicly traded firms quoted in the London Stock Exchange.

Design/Methodology/Approach - The model incorporates three existing literatures as an alternative to bankruptcy. The model has two stages: the first stage discriminates financially healthy or distressed firms utilizing Binary Logit Regression while in the second stage with the use of the univariate analysis, firms are further categorized into four possible outcomes: financially healthy, potentially healthy targets and financially distressed or potentially distressed acquisition targets.

Findings - It was found that financial distress could be identified even three years prior the event. Moreover, statistical significant differences were found between the four firm sample groups.

Research limitations / implications - The vast changing environment and the financial crisis, highlight the need for future research on the area that will consider the world trade implications along with the individual macroeconomic variables of each country.

Originality / Value - It is the first time that a model is developed for the United Kingdom to follow the hazard model's procedure based on recent financial data. Moreover, due to the scope of the analysis, a new version of the latter procedure is employed. A further innovation that makes the produced model unique is its ability to classify a firm into one of several a priori groupings according to the latter's individual characteristics. This overcomes the limitation of earlier studies that considered only two possible outcomes for firms.
\end{abstract}

Keywords - Financial Distress, Distress Prediction, Bankruptcy, Merger \& Acquisitions, Merger as an alternative to bankruptcy, strategic management, decision making.

Paper Type - Research Paper

\section{Introduction}

Corporate failure is among the most well researched topics in the finance and strategic management literature. The fast-moving business environment, the intense international competition and the huge amount of money invested daily create the need for investment decision tools that can assist financial institutions and investors to make fast and safe decisions. Academics in response to these needs of the financial sector developed several econometric models, such models are able to identify distress, merger and acquisition targets, as well as firms that although in distress were acquired. Many of these valuable models have limitations when applied to practice because they consider only two possible statuses for firms, for example healthy or distressed. In reality, there are more scenarios, namely healthy (continuing firms), healthy acquired, distressed or distressed acquired and so investors are obliged to combine several models.

The unstable and fast changing business environment, disturb the conditions that enterprises were accustomed to operate, Kaplan \& Norton (1996) and Copeland (2000), Kasipillai (2004). This had as repercussion not only the financial but also organizational decline, along with severe changes in global employment and economic welfare. The latter phenomenon attracted the attention of the economic authorities and academics. This topic is well timed, since globe still 
experience a historical worldwide financial crisis, which force many countries to the edge of collapse and historical corporations into bankruptcy.

On a technical level there has been an increase in the number of accounting quantitative studies investigating the "business failure" theme due to an increase in the availability of reliable data and rapid progress in statistical, mathematical techniques and informatics. Many researchers investigating this area consider that the main reason for corporate failure is "mismanagement". Boritz et al. (2007) analysed a large number of small business failures in Canada and concluded that some type of managerial incompetence was responsible for almost all failures. Altman (1984) supported Knight's view by describing corporations as "black boxes" that their environment and stakeholders are moving them in their hands. In contrary, other investigators such as Laitinen (1991) and Keasey and Watson (1990) depict corporate failure as a dynamic process.

The purpose of this study is to identify financial ratios that can be used to evaluate and predict corporate financial distress in publicly traded firms quoted on capital markets. The models developed overcome limitations developed in previous studies by taking a more nuanced approach to the treatment of financial circumstances of companies. Thus a two-stage approach was developed to model which firms are categorized as healthy or distressed. In a subsequent stage of analysis the model categorizes both types of firms as potential Merger and Acquisition targets or not. The paper contends that by developing predictive models, financial decision makers may have a larger spectrum of information to assist them in formulating their decisions.

The paper is organized as follows. In section 2, the related empirical literature is discussed. Section 3 describes the data and discusses the methodology. Sections 4 and 5 develop the main research hypotheses and present the empirical results. Finally, our conclusions and recommendations for future research appear in section 6.

\section{Literature Review}

\subsection{Distress Prediction}

A cornerstone study on Distress Prediction which allowed researchers to comprehend how an enterprise enters a failure path is this by Beaver (1968). Most of the studies that have been published since have replicated, developed or provided specialized versions of failure predictions models for different types of corporations, industries and institutional settings (e.g. country differences).

In Altman's MDA model the sample utilized continuing firms that were pair matched with failed firms on the grounds of industry, size and fiscal year. The financial ratios sought to identify different aspects of each firm, such as, profitability, liquidity, leverage, solvency and activity ratios. Taffler (1982) created an operational discriminant model for the identification of U.K. firms at risk of failure. The 23 firms used were considered as failed if they were experiencing receivership, voluntary liquidation, winding up by court order or the equivalent, as they were not pair-matched.

Lau's (1987) logit regression model represented an extension of several of the previous corporate failure prediction models, in two distinct ways. Firstly, in her Logit regression model the conventional failing / non-failing dichotomy was not adopted. To approximate the more realistic continuum of corporate financial health, five financial states were used as alternatives. Secondly, instead of "classifying" a company into a certain financial state, the new model estimates the probabilities of a firm entering a particular state.

More recent studies attempted to increase their model accuracies by attempting to overcome the 'Stationarity Problem'. Such non-static models can be distinguished into two broad categories, namely dynamic time-series models and hazard models. One of the most distinct dynamic timeseries models was that of Theodossiou et al. (1996) based on the statistical methodology of timeseries CUSUM (Cumulative Sums) developed by Theodossiou (1993). This version of the financial distress prediction model avoids problems associated with non-stationary variables and the 
definition of financial distress. As Theodossiou (1993), stated explanatory variables included in financial distress models show strong positive serial correlation over time and are very often not stationary.

On the other hand, very influential hazard models are that of Shumway (2001) who argued that hazard models are more appropriate than single-period (static) models such as Altman's (1968) famous Z-score model for predicting bankruptcy, because the latter models produce bankruptcy probabilities that are biased and inconsistent estimates of the probabilities that they approximate. The limitation of the static models arises from the nature of bankruptcy, since it occurs infrequently and forecasters utilize samples that span several years and use one set of explanatory variables in order to estimate their models. However, the characteristics of the companies investigated necessarily change from year to year.

There are three main reasons as to why hazard models may be more preferable in predicting bankruptcy. The first reason is that when the sampling period is long, it is important to realize the fact that some companies file for bankruptcy after many years of being at risk. The second reason is that hazard models encompass explanatory variables that change with time. They exploit each company's time series data by incorporating annual observations as time-varying covariates. Finally, they generate more efficient out of sample forecasts by employing additional data. They can be considered as Binary Logit models that include each firm's financial year as a separate observation. Since the sample utilized in the creation of prediction models has an average of 5 to 10 years of financial data per firm, then the data used in the estimation of the hazard model will be 5 or 10 times greater than that of a static model, leading to more precise parameter estimates and superior forecasts. This drawback of static models was also addressed by Queen and Roll (1987) and Theodossiou (1993), who developed dynamic forecasting models.

In favour of the hazard models approach were Hillgeist et al. (2004) whose arguments were put forward from the fact that there are several reasons to question the probabilities derived from models that are based on accounting data. These financial statements are designed to assess past performance and may not be appropriate in analyzing the future status of the firm, since they are formulated under the going-concern principle. Another important limitation of many accounting based bankruptcy prediction models is their failure to incorporate a measure of asset volatility. The competitiveness of the hazard model procedure in relation to previous models was also reinforced by the findings of Dewaelheyns and Van Hulle (2006).

\subsection{Mergers \& Acquisitions}

Mergers and acquisitions (M\&As) have also attracted the attention of researchers in the literature throughout the years. Mergers and acquisitions are important economically and have been important in real terms as governance for success reasons. First merger activity increases market concentration and may lead to the possible misallocation of resources and abuse of market power. It can also have potential political and social impact (Ekbo, (1983); Kim and Singal, (1996); and Schoenberg and Reeves, (1999)). Secondly, interest in the area also arose from the debate and development of maximising theories of the firm. Levine and Aaronovitch (1981) and Palepu Palepu (1986), indicated that mergers are instruments that allow corporations to grow fast, become large and more efficient by taking advantage of economies of scale and thus increase competitiveness among enterprises resulting in lower prices to consumers. Large corporate size is also considered by researchers and managers as best if not the best anti-takeover strategy, since targets are almost always smaller in size than their acquirers (Dietrich and Sorensen, (1984); Cudd and Duggal, (2000)). A further reason is the possibility to discriminate potential takeover targets which could lead to abnormal returns to any investor.

Research papers on mergers and acquisitions can be categorised into three types. Firstly a number of empirical studies have attempted to construct statistical models that are able to predict targets for acquisition using publicly available financial information. These models compare 
financial features of companies that were acquired with those of non-target companies using the same methodology as distress prediction models. The purpose is to highlight discriminating characteristics of potential targets in order to predict which firms are probable takeover targets. Influential papers on this category are those of Dietrich and Sorensen (1984), Palepu (1986), Powell (1997), Camerlynck et al (2005), Cigola and Modesti (2008), and Campbell et al. (2008). This category is strongly associated with this study, which compares targets and non-targets. The other two categories are the post- takeover studies ${ }^{1}$ and finally those studies that examine the posttakeover performance of the acquirers to the pre-takeover characteristics of the firms involved ${ }^{2}$ (Bruner (1988) and Smith and Kim Smith and Kim (1994)).

Empirical studies in the area of mergers and acquisitions have produced different empirical findings regarding the performance of the target firms prior to acquisition. Researchers such as Palepu (1986) came to the conclusion that acquired firms were underperformers in comparison to their industry median; this is contrary to the findings of Comerlynck and Ooghe (2005), on the other hand could not identify any differential characteristic between the two groups. This diversity may be is the result of the different financial states of the target firms. The latter view is supported by several researchers of the area such as Pastena and Ruland (1986).

The comprehension of the factors that encourage the decision to acquire a financially distressed firm is an important issue with significant implications for investors, shareholders, bondholders and managers. The gains of acquiring a distressed corporation for the investor are the same as mentioned earlier in the advantages of predicting mergers and acquisitions only in this case the increases of share values are much higher (Clark and Weinstein, (1983)).

Evidence in support of this bankruptcy avoidance rationale for mergers is given by Shrieves and Donald (1979), who believe that many situations of severe financial crises among large corporations are resolved through the merger process.

\section{Data and Methodology of the Distress Prediction}

\subsection{Logit Modeling}

The distress classification is attempted by using Binary Logistic analysis. It is a technique that several studies which investigated the distress classification and prediction, have utilised (Shumway (2001); Hillgeist et al (2004); Campbell et al. (2008)). Binary Logistic analysis, aims to identify the best fitting and most parsimonious yet statistically reasonable model to describe the relationship between an outcome (in this case a dependent variable) and a set of independent (predictors or explanatory) variables. The main distinguishing characteristic of logistic regression from linear regression is that the dependent variable in logistic regression is categorical and most usually binary or dichotomous (as in this case where the outcome is either Healthy or Distressed). The latter has the advantage of more precise weights for the variables in the produced model than a model considering more than two different levels of the dependent variable.

Additionally, in order the model to be able to consider the case that firms change through time and thus overcome the disadvantages of static models (which are single period classification models estimated on the basis of financial information one year prior to bankruptcy (Shumway (2001)), the hazard procedure based on the number of firms file for bankruptcy after years of being in distress.

\footnotetext{
${ }^{1}$ Many of these studies look into both the pre-takeover performance of the target and the acquiring firm and sometimes the posttakeover performance of the acquiring firm. Publications that focus only on the differences between acquirers and targets are those of: Levine and Aaronovitch (1981) and Gorton et al (2009). Researchers that have investigated the post- takeover period are Cosh et al (2006).

${ }^{2}$ A number of studies have tried to find linkages between the post-takeover performance of the acquirers and the pre-takeover characteristics of the firms that are involved in the takeover. Notable studies are those of: Parrino and Harris (1999). Other researchers who examine the possible financial motive for mergers and acquisitions based upon a complementary fit between acquirers and targets are Bruner (1988) and Smith and Kim (1994).
} 
This study employs a new version of the hazard model procedure. Instead of classifying a distressed firm as "survived" till the year prior to the event of failure, in this analysis it is classified as distressed for all the five financial years considered in the model. This difference arises from the need of the model to be very sensitive in identifying early signs of distress and not just bankruptcy as prior models did. The latter approach can be also justified on the grounds that many important studies on the area of Bankruptcy Prediction, such as the pioneering work of Beaver (1968) identified significant distress characteristics in firms, five years prior to the event of failure. Moreover, due to this hazard procedure the model does not need to consider trends in the financial ratios.

\subsection{The sample}

The analysis of the first stage of the model concentrates on the financial condition of firms (Healthy or Distressed) and is based upon a set of 76 distressed/non-survived and continuing U.K companies over the period 1998-2003. The financial characteristics for each firm were retrieved from the WorldScope European Disclosure database. The coverage of firms employed in this study is compatible with that of previous studies in the area of corporate failure, such as Beaver (1968), and Taffler (1982) which used relatively small size samples and a mix of industries (Keasey and McGuiness, (1990), mainly manufacturing and retailing.

The distress prediction model employs financial statement data. Out of the 76 firms in the sample, 38 experienced either bankruptcy or distress characteristics in the period of study in the form of Liquidation, Voluntary Liquidation (firms in this category were identified as distressed using Clark and Ofek (1994) distress criteria and LexisNexis database), Winding-Up, Appointment of an Administrator, or Receiver, or Liquidator, Cancellation of Listing in the London Stock Exchange for not meeting the financial criteria of the London Stock Exchange ${ }^{3}$. The use of additional forms of financial distress differentiates this study as previous researchers used in their samples only bankrupt firms. This differentiation arises from the target of the model, which is to identify and predict corporate distress. Therefore the utilization of only bankrupt corporations would be inappropriate, since bankruptcy is the most severe case of distress (Theodossiou et al, (1996)).

The remaining 38 firms included in the sample are continuing firms (meaning that they were still trading on the L.S.E at the time of the analysis and at least 2 more years after) pair-matched with the distressed firms in accordance to fiscal year, industry and size measured from their total assets, five years prior the event of Liquidation, De-listing etc.

\subsection{The distress sample}

As noted above due to the scope of the analysis, which is the prediction of financial distress, a broader definition of failures was used for the inclusion of potential firms. Theodossiou et al (1996) argued that by employing bankrupt firms incorrect inferences could be drawn from the explanatory variables as bankruptcy is a severe form of distress. To identify the distress group Hemscott Financial Services's was employed in order to explore the list of 'Companies that were removed from database. All the firms incorporated in the sample were removed for one of the following reasons: Liquidation, Voluntary Liquidation, Winding Up, Appointment of Administrator / Receivers / Liquidator, Cancellation of Listing and finally for not meeting the L.S.E criteria. The distressed firms were double checked for possible name changes using Hemscott's List of 'Companies Name Changes' that could make them look as "dead". The firms identified as removed from Hemscott were further checked by being identified in the WorldScope European Disclosure database in the "U.K Dead Stock" file (this file does not include the reason of removal). In total 58

\footnotetext{
${ }^{3}$ Firms are de-listed from the Stock Exchange because they violated the Stock Exchange regulations or did not meet its financial specifications.
} 
distressed firms were found in the Hemscott list of 'Companies that were removed from database' but for only 38 of them could the relevant financial data be retrieved from the WorldScope European Disclosure database so the usable sample was 38 firms. Table I identifies the incidence of usable firms over the study period and lists the reasons for removal from Hemscott Financial Services Lists under various headings of failure.

Table I: Number of Distress Firms Employed in the Analysis Reasons for 'Removal from Hemscott Financial Services List'.

\begin{tabular}{cclc}
\hline Year & Number of Firms & Reason for Removal & No of Firms \\
\hline 1998 & 7 & Administration & 7 \\
1999 & 3 & Receivership & 13 \\
2000 & 6 & De-listed & 11 \\
2001 & 3 & Continued Suspension & 1 \\
2002 & 10 & F.T Criteria not satisfied & 1 \\
2003 & 9 & Liquidation & 3 \\
& & Voluntary Liquidation & 2 \\
Total & $\mathbf{3 8}$ & & $\mathbf{3 8}$ \\
\hline
\end{tabular}

\subsection{The continuing sample}

The amount of continuing firms is based on the sample of the distress group. Continuing firms were selected according to industry, total assets and year of 'distress' of the distress sample firms. Additional criteria used in selecting the continuing entities were the existence for at least two years after the 'Distress Year' of the pair-matched partner and the availability of financial statements in the WorldScope European Disclosure database for all of the five years used in this analysis. It is important to mention that no further actions were taken to check the financial condition of the continuing group as Taffler (1982) has already covered it. He mainly used an investment analyst from a leading financial corporation to ascertain if the continuing firms included in his model were actually healthy solvent.

\subsection{Independent Variable Selection}

Many studies undertaken in this area employ a number of different financial ratios as independent variables calculated from the disclosed financial statements of the firms incorporated in their samples. In a similar way, the present study uses financial ratios that a number of studies (Beaver (1968); Ohlson (1980); Keasey and Watson (1990); Zhang et al. (1999); and Neophytou and Molinero (2004)) have identified. The selected financial ratios were used as indicators of financial structure and performance. Non-financial variables were not included due to the difficulty of obtaining accurate data for all the firms and especially for those included in the distressed/ bankrupt group.

\section{Empirical findings for the distress prediction model}

\subsection{The Computation of the Distress Prediction Model}

After the utilization of Stepwise Discriminant Analysis and Backward Discriminant Analysis on a two year data for every firm in the sample (from a list of ten potential significant variables) only five variables where found to be statistically significant. These are:

R1: Working Capital to Market Value (MV) plus Total Debt (DT) : Working Capital is the difference between current assets and current liabilities (ie CA-C.L) A negative value for this ratio signals that the firm might encounter problems in meeting its short term obligations because there 
are not enough current assets to cover them. On the other hand, a company has a lower probability of encountering problems in meeting its short term obligations when the ratio is positive ${ }^{4}$. A version of this ratio (Working Capital / Total Assets) was found significant by Ezzamel and Molinero (1990) and Zhang et al. (1999).

R2: Total Debt to Market Value plus Total Debt: This ratio measures to what extent borrowed funds have been utilized to finance the company's operations. It can give insights on the financial and managerial conditions of a firm. This variable was the least significant of the four variables utilized in the produced model developed in this research. This ratio was found to have high discriminatory power by Ezzamel and Molinero (1990), Laitinen (1991) and Neophytou and Molinero (2004).

R3: Pre-Tax Earnings to Market Value plus Total Debt: It is a measure of the return on assets (ROA) given by both creditors and owners and gives valuable information on how efficiently resources are managed. The definition of pre-tax income is annual income before tax, or operating revenue excluding all expenses except income taxes. The latter ratio was employed by Betts and Belhoul (1987).

R4: Earnings Before Interest and Tax to Market Value plus Total Debt: This ratio estimates how efficiently a firm can earn profit from its assets, regardless of its size and without being affected by management financial decisions. A high value of this ratio can provide a sign of solid operational performance. This ratio was used by Ezzamel and Molinero (1990).

MVTD: Log of Market Value plus Total Debt (LGMVTD): It is a measure of a firm's Total Assets. The importance of this variable has been highlighted in the area of bankruptcy prediction. The ratio employed is transformed to logarithm form.

However, when Correlation Analysis was performed (see Table II) the explanatory variables R3 [Pre Tax Earnings / (Market Value + Total Debt)] and R4 [Earnings before Interest and Taxes/ (Market Value + Total Debt)], were found to be highly correlated. Since the financial ratio R3 was more statistically significant than financial ratio R4, the latter ratio (meaning R4) was discarded with minimum loss of prediction accuracy.

Table II: Correlation Analysis Using 2-Year Data

\begin{tabular}{llllll}
\hline Variables & R1 & R2 & R3 & M4 & \multicolumn{1}{l}{ MVTD } \\
\hline R1 & 1 & $.356^{* *}$ & $.366^{* *}$ & \multicolumn{1}{l}{-.126} & $-.162^{*}$ \\
R2 & -.126 & .077 & .095 & 1 & $-.187^{*}$ \\
R3 & $.366^{* *}$ & $.995^{* *}$ & 1 & .095 & $-.255^{* *}$ \\
R4 & $.356^{* *}$ & 1 & $.995^{* *}$ & .077 & $-.197^{*}$ \\
MVTD & $-.162^{*}$ & $-.197^{*}$ & $-.255^{* *}$ & $-.187^{*}$ & 1 \\
\hline
\end{tabular}

*.Correlation is significant at the 0.05 level (2-tailed).

**. Correlation is significant at the 0.01 level (2-tailed).

With the employment of the four significant explanatory variables and with the utilization of five year data for every firm in the sample the Binary Logit Model was constructed. Variable MVTD (Market Value + Total Debt) was transformed to Logarithm because it provided a better fit for the model.

\footnotetext{
${ }^{4}$ It should be noted that industry differences make such generalisations problematic. For example, healthy retail companies commonly display negative working capital ratios. This issue underlines the importance of industry sector matching.
} 
The estimated model's variables and weights are listed below:

$\mathrm{Z}=-2.8 *$ Constant $+1.29 * \mathrm{R} 1-1.34 \mathrm{R} 2+1.68 \mathrm{R} 3+0.65$ LGMVTD.

The first part of the estimation output, when running the Binary Logistic Analysis (i.e. to identify distress) is presented in Table III. The header title provides basic information about the estimation technique, in this case Binary Logit Regression. The lower part of the estimation output, displays the variables used in the equation, coefficient estimates, asymptotic standard errors, $\mathrm{z}$-statistics and corresponding p-values respectively. The row 'variables' are the four variables that were found to have significant discriminatory power.

Table III: Model's Equation

\begin{tabular}{lllll}
\hline Method: ML - Binary Logit & & & \\
Variable & Coefficient & Std. Error & z-Statistic & Prob. \\
Constant & -2.8 & 1.06 & -2.64 & 0.008 \\
R1 & 1.29 & 0.38 & 3.44 & 0.001 \\
R2 & -1.34 & 0.62 & -2.16 & 0.031 \\
R3 & 1.68 & 0.7 & 2.39 & 0.017 \\
LGMVTD & 0.65 & 0.22 & 2.96 & 0.003
\end{tabular}

Note: The variables used to estimate the model, are computed over a period of five years prior to bankruptcy. Each firm's financial year is considered as a separate observation. Coefficient column depicts the regression coefficients. Coefficient (C) is the intercept and the remainder is slope coefficients. The positive square root of the variance is the Standard Error. The Z-score is calculated by subtracting from the data the set's average from each member of the set, and then divide each member of the set by the set's standard deviation. The probability column reports the significance level of the variables.

Having named the statistical characteristics of the explanatory variables of the distress prediction model, we turn now to a discussion of the model's classification accuracy. The classification results of the produced Binary Logistic model are provided in the Table IV. The model uses a cut-off value of 0.5 for classifying firms as distressed or healthy. Apart from the missing values, the data set compresses five years data for 76 firms giving 371 observations in total.

Table IV, Panel B reports the classification performance for two years prior to "failure", while the total prediction power of the model drops to $70 \%$. The classification accuracy for the distress sub-group is $63 \%$, whilst $76 \%$ of the continuing sub group is correctly classified. Further, Panel C of Table IV shows that when the model is applied to data for three years prior to failure, the model's total accuracy drops to $66 \%$. This reduction is caused by the sharp drop in the correct classifications of the distress group (falling to $47 \%$ from $63 \%$ two years prior failure).

The sharp fall to low percentage accuracy for the distress group indicates that the model has a two years horizon; meaning that for 3 or more years before failure the probability of a Type I Error (classifying distressed firms as healthy) is significantly high. It is important to state here that the model consistently misclassified one continuing firm in every year that the model was tested. As this was unexpected the firm was further examined using data from the LexisNexis database. The result of this investigation showed that the firm although defined as continuing, it was actually in the period of study facing serious financial problems. Thus the model correctly classified it as distressed $^{5}$.

\footnotetext{
${ }^{5}$ The firm was Heart of Midlothian Plc. The firm had continuing management difficulties and annual profit losses (e.g. in year 2000 the firm experienced losses of GBP 3.5 millions and in year 2001 the net loss was equal to GBP 3.8millions.
} 
Table IV: Classification Accuracy Year -1, -2, -3 from Failure

\begin{tabular}{|c|c|c|c|}
\hline \multicolumn{4}{|c|}{ Panel A: Total Classification Accuracy Year -1 } \\
\hline & Distress & Continuing & Total \\
\hline Total & 38 & 38 & 76 \\
\hline Correct & 32 & 28 & 60 \\
\hline Incorrect & 6 & 10 & 16 \\
\hline$\%$ Correct & $84.20 \%$ & $73.70 \%$ & $79 \%$ \\
\hline \multicolumn{4}{|c|}{ Panel B: Total Classification Accuracy Year - 2} \\
\hline & Distress & Continuing & Total \\
\hline Total & 38 & 38 & 76 \\
\hline Correct & 24 & 29 & 53 \\
\hline Incorrect & 14 & 9 & 23 \\
\hline$\%$ Correct & $63.16 \%$ & $76.30 \%$ & $70 \%$ \\
\hline$\%$ Incorrect & $36.84 \%$ & $23.70 \%$ & $30 \%$ \\
\hline$\%$ Incorrect & $15.80 \%$ & $26.30 \%$ & $21 \%$ \\
\hline \multicolumn{4}{|c|}{ Panel C: Total Classification Accuracy Year -3 } \\
\hline & Distress & Continuing & Total \\
\hline Total & 36 & 38 & 74 \\
\hline Correct & 17 & 32 & 49 \\
\hline Incorrect & 19 & 6 & 25 \\
\hline$\%$ Correct & $47.20 \%$ & $84.20 \%$ & $66 \%$ \\
\hline$\%$ Incorrect & $52.80 \%$ & $15.80 \%$ & $34 \%$ \\
\hline
\end{tabular}

\subsection{Out of Sample Test of the Distress Prediction Model}

To test the discriminating power of the distress prediction model, an out-of-sample of U.K quoted firms was created arising from the same industries of those firms utilised in the estimation of the distress prediction model. This sample was drawn from Hemscott Financial Services lists of "Companies that were removed from database" for the study period. Financial statements and other information for each firm in the sample were collected from the WorldScope European Disclosure and LexisNexis Databases. As with the estimation sample, banks, financial institutions and insurance companies were excluded from this sample due to their different accounting methods. The list of firms, used to construct the out of sample list, incorporates a number of categories of failure as Figure 1 indicates:

\begin{tabular}{cc}
\hline No of Firms & $\begin{array}{c}\text { Reason for } \\
\text { Exclusion }\end{array}$ \\
\hline 6 & Acquisition \\
1 & Bankruptcy \\
1 & Receivership \\
1 & Liquidation
\end{tabular}




\begin{tabular}{cc}
5 & Continuing \\
14 & Total \\
\hline
\end{tabular}

Figure 1: Out-of-Sample Firms' Categories

The six firms belonging to the Acquisition Group were examined for distress features according to International Distress Characteristics outlined by Clark and Ofek (1994). The result of the analysis indicated that four of them were healthy targets and the remaining distressed. The reason that acquisition targets were included was to investigate if the model was able to discriminate not only the financial condition of Continuing and Distressed firms, but also Healthy and Distressed targets (an approach used also by Clark and Ofek (1994)). Moreover, the inclusion of firms subject to merger and acquisitions, highlights the importance of this alternative in the context of corporate distress research (Jones and Hensher, (2007)). Table V shows the model's accuracies in classifying out of sample firms one, two and three years prior to the event of failure.

In year one prior to the event (failure, acquisition or year of investigation for the continuing firms) the model was able to classify correctly thirteen firms from the total of fourteen out of sample firms with only misclassifying Barcom PLC. Thus, the prediction accuracy of the model one year prior to the event is equal to $92.8 \%$. Further, in year two prior to the event year or year of investigation, the model correctly classified twelve out of the fourteen sample firms. The firms that were misclassified were Barcom PLC and Meristem PLC. Therefore the models accuracy dropped to $85.7 \%$. Finally, three years prior the event, the distress prediction model accuracy falls even more to $71.4 \%$, since it misclassified four companies. The firms that were classified incorrectly were: Barcom PLC, Meristem PLC, Leslie Wise Group PLC and Hollas Group. However, Meristem PLC in years two and three prior to its acquisition, although it was facing problems (issuing profit warnings) and the stock price was going down, the firm still manage to have pre-tax profits.

Nevertheless, the discriminatory ability of the model is consistent with that of Ohslon (1980) and Altman (2002) models. In more details, the model attained an accuracy rate of $79 \%$ one year prior to failure, $70 \%$ two years prior to failure and $60 \%$ three years prior to failure. The model's results are consistent with earlier models developed for the U.K. although for the estimation sample the models estimated by Keasey and McGuiness (1990) and Charitou et al (2004) achieved higher classification accuracies (88\%, 96\%, 86\% and 94\% respectively, one year prior to failure). However, the model developed in this study proved to be more accurate in predicting distress in the out-of-sample test. It achieved an accuracy of $93 \%$ a year prior to failure and accuracies of $86 \%$ and $71.5 \%$ two and three years respectively prior to failure. These are higher accuracies than those achieved by earlier U.K models. 
TABLE V: Out of Sample Classification Test: Years -1 to -3

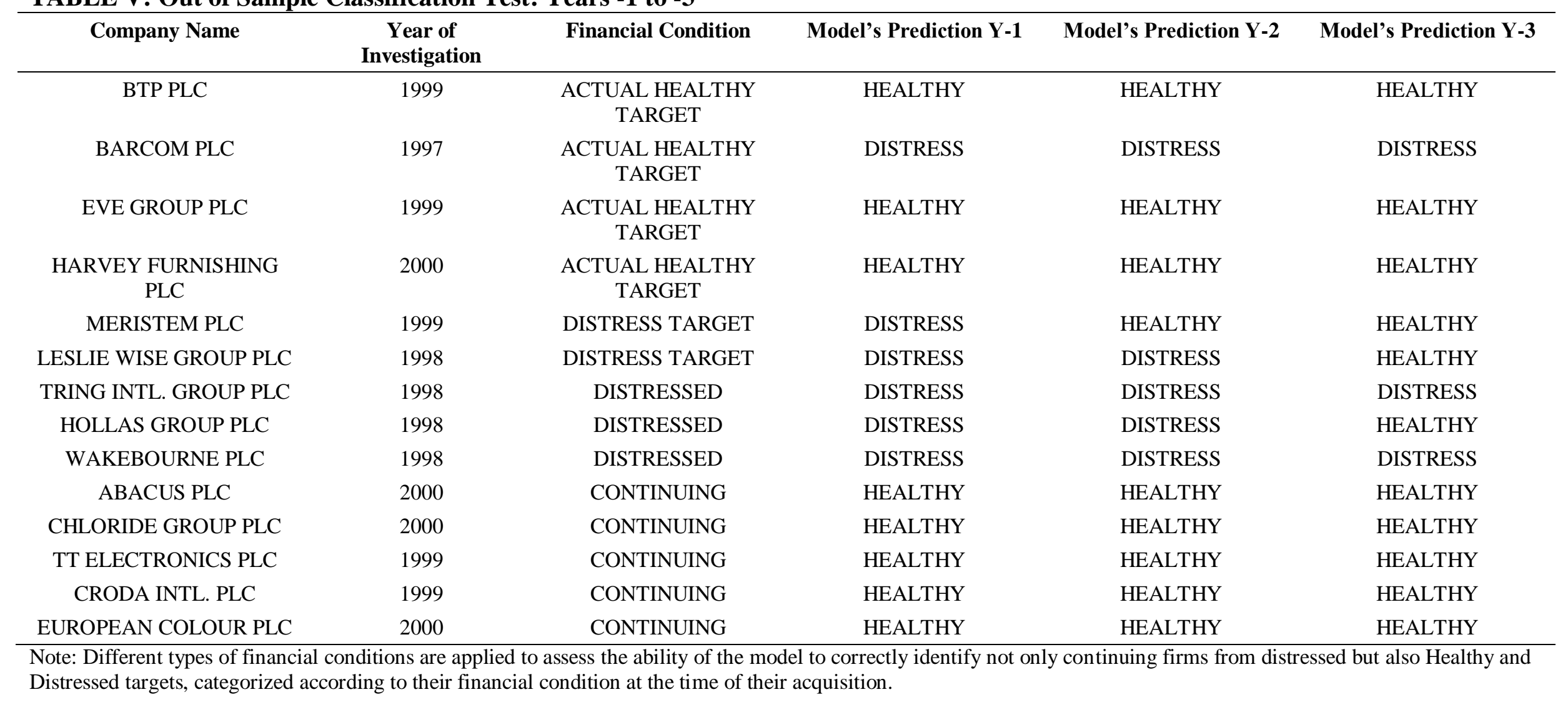




\subsection{A model of merger \& acquisition prediction}

At this stage, our prediction model considers the financial conditions that may tend to increase the probability of a firm becoming a takeover target. Thus it uses a sample of target/non-target U.K companies for which financial statements can be retrieved from the WorldScope European Disclosure database for the period 1998-2003.

The data set used in the model building is consistent with those of previous studies in the area of predicting mergers and acquisition targets, such as Palepu (1986), and Camerlynck et al. (2005), all of whom employed samples from a variety of different industries but concentrating upon mainly manufacturing and retailing. It is important to mention here that the structure of the sample used in this study is based upon the following structural elements. Firstly, the industries of firms employed in this second part of the model are compatible with the industries used in the first part, namely the distress prediction model. Secondly, a pair-matching design was used in the analysis of continuing operations versus healthy targets, according to industry, year and size. As we shall see, this design could not be applicable in the analysis of distress targets (17 firms) versus distress firms (23 firms) presented later in this study. The main reason is the small numbers of firms in the two groups which were creating difficulties in the evidence of observations and were reflecting the real economic occurrence of such cases. Finally, as in the model of distress prediction companies, operating industries i.e. banking, insurance and finance were excluded because of their different accounting methods.

\subsection{The Merger and Acquisition Target Groups}

The model takes into account Mergers and Acquisitions in the U.K for the same sample period 1998-2003 as in distress prediction model. All mergers and acquisitions used in this section were identified by Hemscott Financial Services lists "U.K Mergers and Acquisitions" where the names of firms that became acquisition targets are reported. For every firm, selected data for the last five years prior to the event were collected. Similarly, as in the distress prediction model, financial information was collected from the WorldScope European Database and those data includes the Balance Sheet, Profit and Loss Account, Cash-flow statement, key financial ratios (provided by the WorldScope database), and the number, price and market value of the shares of the companies (184 firms overall).

Every target firms of merger and acquisitions used in this part of the research was checked to determine whether they displayed distress characteristics. In this part, we follow the procedure implemented by Clark and Ofek (1994). The prediction model developed was not utilized in this part of the analysis to classify the firms as "Healthy" or "Distressed", because of possible misclassification errors that exist in every prediction model developed. Therefore, by employing the methodology developed by Clark and Ofek (1994) the latter issue was overcome. A firm that did not meet the majority of the criteria two years prior the event was considered as "Distressed".

Taking into consideration the international distress characteristics mentioned above, each of the 89 target firms of merger and acquisitions identified in the Hemscott lists as mergers and/or acquisitions targets was categorized as either distressed (in this case "distressed target") or healthy (in this case "healthy target") firms. From the sample of 89 firms listed in Hemscott, seventy two firms were classified to be healthy targets and seventeen distressed target firms at the time of acquisition.

Having identified the sample of 89 firms involved in merger and acquisitions (sub-divided into distressed, 17 firms and healthy 72 firms sub-samples) a comparative sample of non merger and/or acquisition targets was constructed. The sample of continuing (non-target) firms was based on the healthy target sub-sample group. The continuing firms were chosen matched on the total assets and the industry in which they operate five years prior the event of acquisition. The financial data collected for each continuing firm in this group was according to the year of M\&A of the 
target merger and acquisition firm with which it was pair-matched and still in existence even two years after the period of the analysis.

\section{Empirical findings for the Mergers and Acquisitions prediction model}

In the second part of the estimated model, univariety analysis was implemented. Univariate analysis is conventional approach to financial statement analysis where variables are examined individually to assess inter alia the profitability, liquidity and gearing of an enterprise. This approach gives much attention to the numbers drawn from financial statements but fails to recognize interactions between the variables. The latter causes concerns to the potential user who has to verify the behavior and the values of the results, taking into account they can generate by various combinations of economic events.

Moreover, the analyst also faces the problem of identifying appropriate benchmarks for every financial ratio calculated. Nevertheless and despite these problems with the employment of pair-matched research design, several researchers such as Levine and Aaronovitch (1981) highlighted this approach as successful in discriminating failed - non failed and acquired with nonacquired companies.

There were several reasons for applying Univariate Analysis instead of Binary Logistic regression in the second part of the model. Firstly the scope of the analysis was to identify the characteristics of Merger and Acquisition targets. Hence, Logit regression was not required to distinguish the firm groups (Continuing-Healthy Targets firms, Distress-Distressed Target firms and Healthy Targets-Distress Target firms).

Secondly, depending on the methodology applied, there are two different sets of concerns. In the first case, if all groups of firms (Continuing, Healthy Targets, Distress Targets and Distressed firms) were used in the estimation of the distress prediction model (part one of the produced model) and the results of the latter were used for the estimation of the second (part two of the produced model), then, the statistical errors (misclassifications, ie Type I and Type II errors) from the first model may have a detrimental effect on the estimation of the variable weights, the accuracy and the significance of the second model. In the second case, where two different samples were used in each part of the model (parts one and two), the firms selected for analysis at part two depend on the selections made at part one. Therefore, any probability analysis at part two of the model will not have the usual properties, because it is conditional on part one (i.e the data is not random sample as it is required). Moreover, the sample sizes of Distress Targets and Distressed firms were too small for a model to be estimated. Additionally, the motives behind an acquisition of a healthy firm cannot be reflected into financial statements.

\subsection{The Explanatory Variables for the Merger and Acquisition Prediction Model}

Studies that predict mergers and acquisitions have used a variety of different financial ratios as independent variables, arising from the financial statements for the firms included in their samples. Using previous studies as the basis, this study employs many of the financial ratios used by other researchers and does not seek new financial ratios as explanatory variables. The independent variables utilised in this study were chosen according to the following criteria:

i) Financial ratios which had been popular in the literature of prediction of merger and acquisition targets. The studies of Dietrich and Sorensen (1984) were specifically used.

ii) Financial ratios utilised in studies of mergers as an alternative to bankruptcy by Theodossiou et al. (1996). 


\subsection{Comparison Between Continuing and Healthy Targets}

After the use of the independent t-test, Mann-Whitney U test and correlation analysis from the list of potentially useful ratios, only four were found to be significant in comparison of continuing firms and healthy targets of mergers and acquisitions.

The Univariate analysis (see Table VI) indicates that in the United Kingdom, public traded 'healthy' firms that are more profitable than other continuing firms, have a higher probability of becoming takeover targets. The latter result highlights i.e. targets are more successful in generating profits, supports the findings of Franks and Mayer (1996), Camerlynck et al. (2005). Panel A of Table VI, shows a characteristic of the continuing firms (non-acquired) which was identified by the reported Univariate analysis.

Table VI: Descriptive Statistics on Healthy Targets and Continuing Firms

\begin{tabular}{|c|c|c|c|c|c|c|c|c|}
\hline \multicolumn{9}{|c|}{ Panel A: Healthy Targets versus Continuing Firms } \\
\hline Status & & & $\mathbf{N}$ & Min & Max & Mean & Median & Std.Dev \\
\hline \multirow{5}{*}{$\begin{array}{l}\text { Healthy } \\
\text { Target }\end{array}$} & $\begin{array}{l}\text { Operating Income/ } \\
\text { Value+ Total Debt) }\end{array}$ & (Market & 215 & -0.86 & 1.9 & 0.11 & 0.1 & 0.15 \\
\hline & Operating Profit Margin & & 213 & -83.6 & 27.6 & 8.5 & 7.5 & 8.8 \\
\hline & Published Cash EPS & & 209 & -32.7 & 180.6 & 25.4 & 21.3 & 24.1 \\
\hline & Valid N & & 208 & & & & & \\
\hline & $\begin{array}{l}\text { Operating Income/ } \\
\text { Value+ Total Debt) }\end{array}$ & (Market & 215 & -0.32 & 0.37 & 0.08 & 0.09 & 0.08 \\
\hline \multirow{3}{*}{ Continuing } & Operating Profit Margin & & 214 & -212.5 & 29.3 & 5.1 & 7.1 & 21.6 \\
\hline & Published Cash EPS & & 213 & -10.2 & 87.5 & 20 & 17.3 & 16.4 \\
\hline & Valid N & & 212 & & & & & \\
\hline
\end{tabular}

Panel B: Continuing Firms versus Healthy Targets

\begin{tabular}{llllllll}
\hline Status & & N & Min & Max & Mean & Median & Std.Dev \\
& & & & & & & 0.0 \\
H. Target & Real Total Assets Growth & 214 & -0.73 & 3.02 & 0.1 & 0.54 \\
& Valid N & 214 & & & & & \\
\multirow{2}{*}{ Continuing } & Real Total Assets Growth & 215 & -0.73 & 5.00 & 0.2 & 0.1 & 0.6 \\
& Valid N & 215 & & & & & \\
\hline
\end{tabular}

The comparison of the Real Total Assets Growth between the two groups (see Table VI, Panel B) illustrate that continuing firms have different business strategies than those of the target firms. It appears they maintain quick assets and they are ready to take advantage of investment opportunitie as acquiring fixed assets. The latter, can be also interpreted as indication of an anti-acquisition policy. This has been raised in the literature by Dietrich and Sorensen (1984), Cudd and Duggal (2000).

\subsection{Comparison Between Distress Targets and Distressed Firms}

When an independent t-test, a Mann-Whitney U test and correlation analysis was employed in the comparison between the distressed targets with distressed firms, 11 independent variables from the 47 potential significant variables utilized in the analysis were found to be statistically significant at a $99 \%, 95 \%$ and a $90 \%$ confidence levels. Because of the limited number of firms involved, the two groups were pair-matched only by industries and not according to year of event and asset size (23 failed firms and 17 distressed targets). For the latter reason, financial data of one year prior the event of failure or merger/acquisition are considered. 
The significant differences between distressed targets and distressed firms illustrated in Panel A of Table VII indicate that the first group of firms (distress targets) are in better financial condition overall. In depth, the findings show that distressed targets are more profitable, which is probably due to the fact they were also found to be more efficient. It is also very important to note that distressed firms that end up as acquisition targets were found to be in a better liquidity state than those who were distressed non-acquired. The findings support findings by Peel and Wilson (1989), Theodossiou et al (1996) and Citron et al (2003) who noted that companies which fail with the most acute financial and cash-flow problems, may be more difficult to sell on a going concern basis as it is likely to be difficult to persuade buyers to take on these difficulties.

Table VII: Descriptive Statistics on Distressed Targets and Distressed Firms

\begin{tabular}{|c|c|c|c|c|c|c|c|}
\hline \multicolumn{8}{|c|}{ Panel A: Distressed Targets versus Distressed Firms } \\
\hline & Status & $\mathbf{N}$ & Min & Max & Mean & Median & Std.Deviation \\
\hline \multirow{4}{*}{ D. Target } & Return on Equity & 17 & -41.65 & 89.36 & -0.7 & -4.4 & 33.7 \\
\hline & $\begin{array}{l}\text { Working Capital/ (Market Value + } \\
\text { Total Debt) }\end{array}$ & 17 & -0.28 & 1.56 & 0.35 & .34 & 0.5 \\
\hline & Inventories Days Held & 17 & 5 & 219 & 90.8 & 96.0 & 64.7 \\
\hline & Valid N & 17 & & & & & \\
\hline \multirow{4}{*}{ Distressed } & Return on Equity & 22 & -430.2 & 115.04 & -55.7 & -27.8 & 108.5 \\
\hline & $\begin{array}{l}\text { Working Capital/ (Market Value + } \\
\text { Total Debt) }\end{array}$ & 23 & -0.74 & 1.2 & -0.02 & -0.06 & 0.5 \\
\hline & Inventories Days Held & 20 & 3 & 145 & 54.45 & 44.0 & 43.1 \\
\hline & Valid $\mathbf{N}$ & 19 & & & & & \\
\hline \multicolumn{8}{|c|}{ Panel B: Distressed Firms versus Distressed Targets } \\
\hline & Status & $\mathbf{N}$ & Min & Max & Mean & Median & Std.Deviation \\
\hline \multirow{3}{*}{ D. Target } & Employment Growth (annually) & 16 & -0.46 & 0.14 & -.0956 & -0.06 & 0.161 \\
\hline & $\begin{array}{l}\text { Total Debt \% Total Capital and } \\
\text { Short Term Debt }\end{array}$ & 17 & 0.00 & 70.2 & 32.7 & 31.7 & 21.4 \\
\hline & Valid $\mathbf{N}$ & 16 & & & & & \\
\hline \multirow{3}{*}{ Distressed } & Employment Growth (annually) & 22 & -0.46 & 1.15 & 0.0923 & 0.025 & 0.38 \\
\hline & $\begin{array}{l}\text { Total Debt\% Total Capital and } \\
\text { Short Term Debt }\end{array}$ & 23 & 0.00 & 104 & 53.1 & 50.0 & 32.6 \\
\hline & Valid $\mathbf{N}$ & 22 & & & & & \\
\hline
\end{tabular}

Table VII, Panel B lists the characteristics of distressed firms in comparison to distress targets. The Employment Growth Annually explanatory variable indicates that the distressed firms have a different strategy to overcome the distress problem. Instead of minimizing their business costs (e.g. by decreasing the number of employees) they seem to attempt to continue their operations as normal. However, considering distress targets it needs more time to sell their products.

On the other hand, Panel B of Table VII also demonstrates that the distressed targets undertake a different strategy. This involves the minimisation of costs producing balance sheets with lower debts figures, a factor that may influence a firm to acquire them even in distress, in contrast to distressed firm considering variable Employment Growth per Year. The latter variable however can be a measurement of firm's size, indicating that restructuring may be very costly for a potential acquirer. Another characteristic that reinforces the notion that the distressed targets are more liquid than the distressed non-acquired is variable: Total Debt \% Total Capital and Short Term Debt (Annually), indicating that they experience fewer debts. This conclusion comes to support the findings of Peel and Wilson (1989) and Theodossiou et al (1996). 


\subsection{Comparison Between Healthy Targets and Distress Targets}

Finally, an investigation to find out the main differences of Healthy Targets and Distressed Targets make sure that the two groups (Healthy Targets and Distress Targets) that were used in the comparisons with continuing and distressed firms respectively are independent. Because the two groups could not be pair-matched and additionally all firms in each group had to be considered in this analysis, only one financial year's data were employed. Taking into consideration the original list of 47 potentially significant ratios, 12 variables were found to have discriminatory power at the 99\%, 95\% and 90\% confidence levels considering data one year prior to the event.

By considering the results of the Descriptive Statistics (see Table VIII) Healthy targets are more efficient in allocating their resources, generating cash from their assets and in controlling their cost and expenses, thus enabling them to achieve greater sales and became more profitable. Another indication of well managed firms that have better strategic goals and planning is that they exhibit strong annual growth in both size and number of employees employed. The results display that the two groups are statistically independent, therefore the two latter comparisons are valid.

Table VIII: Descriptive Statistics: Healthy Targets versus Distressed Targets

\begin{tabular}{|c|c|c|c|c|c|c|c|}
\hline & Status & $\mathrm{N}$ & Min & Max & Mean & Median & $\begin{array}{c}\text { Std. } \\
\text { Deviation }\end{array}$ \\
\hline \multirow{12}{*}{ D.Targets } & EBIT/ (Market Value+ Total Debt) & 17 & -1.06 & 0.27 & -0.06 & 0.1 & 0.28 \\
\hline & $\begin{array}{l}\text { Operating Income / (Market Value+ } \\
\text { Total Debt) }\end{array}$ & 17 & -0.71 & 0.20 & -0.006 & 0.04 & 0.20 \\
\hline & Annual Growth in Total Assets & 17 & -5.7 & 0.34 & -0.234 & -0.24 & 0.27 \\
\hline & Annual Growth in Employment & 17 & -0.46 & 0.14 & -0.096 & -0.6 & 0.16 \\
\hline & Return On Investment Capital & 17 & -19.58 & 25.79 & -1.6 & -0.55 & 10.8 \\
\hline & Operating Profit Margin & 17 & -45.66 & 10.74 & -0.7 & 1.0 & 12 \\
\hline & Pre-Tax Margin & 17 & -17.99 & 17.04 & -2 & -.42 & 7.3 \\
\hline & Cash-Flow/ Sales & 17 & -25.22 & 13.85 & 2.95 & 3.36 & 8.6 \\
\hline & Inventories Days Held & 17 & 5.00 & 219.00 & 90.8 & 96.0 & 64.7 \\
\hline & Published Cash EPS & 17 & -6.49 & 25.25 & 7.6 & 10.36 & 8.8 \\
\hline & $\begin{array}{l}\text { Pre-Tax Income / (Market Value + Total } \\
\text { Debt) }\end{array}$ & 17 & -1.15 & 0.24 & -0.09 & -0.01 & 0.3 \\
\hline & Valid N & 17 & & & & & \\
\hline \multirow{12}{*}{ H.Targets } & EBIT/ (Market Value+ Total Debt) & 72 & -0.36 & 0.96 & 0.12 & 0.11 & 0.16 \\
\hline & $\begin{array}{l}\text { Operating Income / (Market Value+ } \\
\text { Total Debt) }\end{array}$ & 72 & -0.86 & 0.41 & 0.1 & 0.1 & 0.13 \\
\hline & Annual Growth in Total Assets & 72 & -0.68 & 2.03 & -0.13 & -0.05 & 0.41 \\
\hline & Annual Growth in Employment & 71 & -0.31 & 0.53 & 0.06 & 0.05 & 0.15 \\
\hline & Return On Investment Capital & 70 & -42.77 & 61.43 & 12.7 & 13.1 & 16.3 \\
\hline & Operating Profit Margin & 71 & -83.62 & 27.63 & 7.5 & 7.4 & 12.6 \\
\hline & Pre-Tax Margin & 71 & -82.59 & 26.06 & 5.4 & 6.35 & 13.7 \\
\hline & Cash-Flow/ Sales & 71 & -6.31 & 32.02 & 9.6 & 8.44 & 6.8 \\
\hline & Inventories Days Held & 64 & 1.00 & 236.00 & 60.1 & 48.5 & 49.04 \\
\hline & Published Cash EPS & 71 & -32.72 & 180.59 & 27.3 & 20.5 & 28.6 \\
\hline & $\begin{array}{l}\text { Pre-Tax Income / (Market Value + Total } \\
\text { Debt) }\end{array}$ & 72 & -0.38 & 0.94 & 0.1 & 0.09 & 0.2 \\
\hline & Valid N & 61 & & & & & \\
\hline
\end{tabular}




\section{Conclusions}

The purpose of this study has been to evaluate and predict financial distress and potential merger and acquisition targets in publicly traded firms on the London Stock Exchange utilizing financial ratios. The model developed is differentiated from earlier models through it presents a number of innovations. It is based on recent financial data making it appropriate since in different periods the occurrence of financial distress is different.

Another innovation that makes the produced model unique is its ability to classify a firm into one of several a priori groupings according to the latter's individual characteristics. Since the model has a larger spectrum of possible outcomes, a two stage approach was adapted. In the first stage firms are categorized as healthy or distressed while in the subsequent stage the model categorizes the latter two categories as potential targets for merger and acquisition or not, providing financial decision makers a larger spectrum of information to assist then when formulating their decisions.

Our analysis shows that efficient firms which operate their resources are more liquid on meeting short term obligations and borrow fewer funds to finance operations. On the same time they are larger in terms of total assets and have less probability of experiencing financial distress or even bankruptcy.

The results obtained from the second part of the model indicate that firms that do not experience financial distress, have more probabilities of becoming merger and acquisition targets than other "healthy" firms if they exhibiting higher profitability and efficiency in their operations. It has been identified that higher probabilities of being acquired had the firms that although in distress were more profitable, they borrowed less to maintain operations, were more efficient in controlling cost and generating profit, and smaller in size than those that went bankrupt.

The continuing changing business environment that brings forward uncertainty to the investors' world confirms the richness and the importance of the subject, therefore more research should be aimed firstly in overcoming the dichotonomous classification limitations and secondly we believe that the inclusion of macroeconomic variables as well as non-financial ratios, will probably lead in higher predictive abilities for the developed models.

\section{Bibliography}

Altman, E. (1968), Financial ratios, discriminant analysis, and the prediction of corporate bankruptcy, Journal of Finance, Vol. 23, pp.589-609.

Altman, E. (1984), The success of business failure prediction models: An international survey, Journal of Banking and Finance, Vol. 8, pp. 171-198.

Altman, E. (2002), Bankruptcy, Credit Risk and High Yield Junk Bonds (New York).

Beaver, W. (1968), The information content of annual earnings announcement, Journal of Accounting Research, Vol. 6, pp.67-92.

Betts, J. and Belhoul D. (1987), The effectiveness of incorporating stability measures In company failure models, Journal of Business Finance and Accounting, Vol. 14, pp. 323-334.

Boritz, J.E., Kennedy, D.B. and Sun J.Y. (2007), Predicting business failures in Canada, Accounting Perspectives, Vol. 6, pp. 141-165.

Bruner, R.F. (1988), The use of excess cash and debt capacity as a motive for merger, Journal of Financial and Quantitative Analysis, Vol. 23, pp. 199-217. 
Camerlynck, J., Ooghe, H. and Langhe T. (2005), Pre-acquisition profile of privately held companies involved in takeovers: An empirical study, Small Business Economics, Vol. 24, pp. 169-186.

Campbell, J.Y., Hilscher, J. and Szilagyi J. (2008), In search of distress risk, Journal of Finance, Vol. 6, pp.2899-2939.

Charitou, A., Neophytou, E. and Charalambous C. (2004), Predicting corporate failure: Empirical evidence for the U.K, European Accounting Review, Vol. 13, pp. 465-497.

Cigola, M. and Modesti P. (2008), A note on mergers and acquisitions, Managerial Finance, Vol. 34, 221-238.

Citron, D., Wright, M., Ball, R. and Rippington F. (2003), Secured creditor recovery rates from management Buy-outs in distress, European Financial Management, Vol. 9, pp. 141-161.

Clark, K. and Ofek E. (1994), Mergers as a means of restructuring distressed firms: An empirical investigation, Journal of Financial and Quantitative Analysis, Vol. 29, pp. 541-565.

Clark, T.A. and Weinstein M. (1983), The behaviour of the common stock for bankrupt firms, Journal of Finance, Vol. 38, pp. 489-504.

Cosh, A., P. M. Guest., and A. Hughes., (2006), "Board Share-Ownership and Takeover Performance", Journal of Business Finance and Accounting, Vol. 33, pp. 459-510

Cudd, M. and Duggal R. (2000), Industry distribution characteristics of financial ratios: An acquisition theory application, Financial Review, Vol. 41, pp. 105-120.

Dewaelheyns, N. and Van Hulle C. (2006), Corporate failure prediction modelling: Distorted by business groups' internal capital markets, Journal of Business Finance and Accounting, Vol. 33, pp. 909-931.

Dietrich, J. K. and Sorensen E. (1984), An application of Logit analysis to prediction of merger targets, Journal of Business Research 12, pp. 393-402.

Eckbo, B. (1983), Horizontal mergers, collusion and stockholder wealth", Journal of Financial Economics 11, Vol., pp. 241-273.

Ezzamel, M. and Mar-Molinero C. (1990), The distributional properties of financial ratios in U.K manufacturing companies, Journal of Business Finance \& Accounting, Vol. 17, pp. 1-27.

Franks, J. and Mayer C. (1996), Hostile takeovers and the correction of managerial failure, Journal of Financial Economics, Vol. 40, pp.163-181.

Gordon, G., Matthias. K. and Rosen, R. J. (2009), Eat or Be Eaten: A Theory of Mergers and Firm Size", Journal of Finance, Vol. 3, pp. 1291-1344.

Hillegeist, S., Keating, E., Cram, D. and Lundstedt K. (2004), Assessing the probability of bankruptcy,, Review of Accounting Studies, Vol. 9, pp. 5-34.

Jones, S. and Hensher D.A. (2007), Modelling corporate failure: A multinomial nested Logit analysis for unordered outcomes, British Accounting Review, Vol. 39, pp. 89-107.

Kasipillai, J. (2004), Tax implications of mergers and acquisitions involving financial institutions, Managerial Finance, Vol. 30, pp. 48-62.

Keasey, K. and McGuiness P. (1990), The failure of UK industrial firms 1976-1984: Logistic analysis and entropy measures', Journal of Business, Finance and Accounting, Vol. 17, pp. 119-135.

Kim, E.H. and Singal V. (1996), Mergers and market power: Evidence from the airline industry, American Economic Review, Vol. 83, pp. 549-569.

Laitinen, E.K. (1991), Financial ratios and different failure processes, Journal of Business Finance \& Accounting, Vol. 18, pp. 649-673.

Lau, L. (1987), A five-state financial distress prediction model, Journal of Accounting Research, Vol. 25, pp. 127-138.

Levine, P. and Aaronovitch S. (1981), The financial characteristics of firms and theories of merger activity, Journal of Industrial Economics, Vol. 30, pp. 149-172. 
Neophytou, E. and Molinero C.M. (2004), Predicting corporate failure in the U.K: A multidimensional scaling approach, Journal of Business Finance \& Accounting, Vol. 31, pp. 677-710.

Ohlson, J. (1980), Financial ratios and the probabilistic prediction of bankruptcy, Journal of Accounting Research, Vol. 18, pp. 109-131.

Palepu, K.G. (1986), Predicting takeover targets, Journal of Accounting \& Economics, Vol. 8, 3-35.

Parrino, J.D., and R. S. Harris, (1999), Takeovers, management replacement, and post acquisition operating performance: Some Evidence from the 1980s, Journal of Applied Corporate Finance, Vol. 11, pp. 88-97.

Pastena, V. and Ruland W. (1986), The Merger / Bankruptcy Alternative, Accounting Review, Vol.61, pp. 288-301.

Peel, M.J. and Wilson N. (1989), The liquidation /merger alternative: Some results for the U.K corporate sector, Managerial and Decision Economics, Vol. 10, 209-220.

Powell, R. (1997), Modelling takeover likelihood, Journal of Business Finance and Accounting, Vol. 24, pp. 1009-1030.

Queen, M. and Roll R. (1987), Firm mortality: Using market indicators to predict survival, Financial Analyst Journal, Vol. 43, pp. 9-26

Schoenberg, R. and Reeves R. (1999), What determines acquisition activity within an industry?, European Management Journal, Vol. 17, pp. 93-98.

Shrieves, R.E. and Stevens D.L. (1979), Bankruptcy avoidance as a motive for merger, Journal of Financial \& Quantitative Analysis, Vol. 14, pp. 501-515.

Shumway, T. (2001), Forecasting bankruptcy more accurately: A simple hazard model, Journal of Business, Vol. 74, pp.101-124.

Smith, R.L. and Kim J.H. (1994), The combined effects of free cash flow and financial slack on bidder and target stock returns, Journal of Business, Vol. 67, pp. 281-310.

Taffler, R.J. (1982), Forecasting company failure in the UK using discriminant analysis and financial ratio data., Journal of the Royal Statistical Society, Vol. 145, pp. 342-358.

Theodossiou, P. (1993), Predicting shifts in the mean of a multivariate time series process: An application in predicting business failures, Journal of the American Statistical Association, Vol. 88, pp. 441-449.

Theodossiou, P., Kahya, E., Saidi, R. and Philippatos G. (1996), Financial distress and corporate acquisitions: Further empirical evidence, Journal of Business Finance \& Accounting, Vol. 23, pp.699-719.

Zhang, G., Hu. M. Y., Patuwo, B.E. and Indro D.C. (1999), Artificial neural networks in bankruptcy prediction: General framework and cross-validation analysis, European Journal of Operational Research, Vol. 116, pp.16-32. 